\title{
Breakdown of 3-(allylsulfonio)propanoates in bacteria from the Roseobacter group yields garlic oil constituents
}

\author{
Anuj Kumar Chhalodia and Jeroen S. Dickschat ${ }^{\star}$
}

\author{
Full Research Paper \\ Address: \\ Kekulé Institute of Organic Chemistry and Biochemistry, University of \\ Bonn, Gerhard-Domagk-Straße 1, 53121 Bonn, Germany \\ Email: \\ Jeroen S. Dickschat ${ }^{\star}$ - dickschat@uni-bonn.de \\ * Corresponding author \\ Keywords: \\ Allium sativum; allyl sulfides; 3-(dimethylsulfonio)propanoate; \\ Roseobacter; volatiles
}

\author{
Beilstein J. Org. Chem. 2021, 17, 569-580. \\ https://doi.org/10.3762/bjoc.17.51 \\ Received: 22 December 2020 \\ Accepted: 19 February 2021 \\ Published: 26 February 2021 \\ This article is part of the thematic issue "Chemical ecology". \\ Guest Editor: C. Beemelmanns \\ (c) 2021 Chhalodia and Dickschat; licensee Beilstein-Institut. \\ License and terms: see end of document.
}

\begin{abstract}
Two analogues of 3-(dimethylsulfonio)propanoate (DMSP), 3-(diallylsulfonio)propanoate (DAllSP), and 3-(allylmethylsulfonio)propanoate (AllMSP), were synthesized and fed to marine bacteria from the Roseobacter clade. These bacteria are able to degrade DMSP into dimethyl sulfide and methanethiol. The DMSP analogues were also degraded, resulting in the release of allylated sulfur volatiles known from garlic. For unknown compounds, structural suggestions were made based on their mass spectrometric fragmentation pattern and confirmed by the synthesis of reference compounds. The results of the feeding experiments allowed to conclude on the substrate tolerance of DMSP degrading enzymes in marine bacteria.
\end{abstract}

\section{Introduction}

The name of the allyl group has been introduced by Wertheim in 1844 when he investigated the constituents of garlic oil and derives from the botanical name of garlic (Allium sativum) [1]. During that time, the structures of the garlic oil constituents and also of the allyl group remained unknown, but its formula was correctly assigned as $\mathrm{C}_{3} \mathrm{H}_{5}$. Five decades later, Semmler reported on the nature of allyl propyl disulfide (1), diallyl disulfide (2), diallyl trisulfide (3), and diallyl tetrasulfide (4) from garlic oil (Scheme 1A) [2]. The antibacterial principle in garlic was identified in 1944 by Cavallito et al. as allicin (5) [3], a formal oxidation product of disulfide $\mathbf{2}$. Not only $\mathbf{5}$, but also several other sulfur compounds from garlic are today known to exhibit diverse biological activities, including inter alia antibacterial, antifungal, antioxidant, anti-inflammatory, and anticancer effects [4]. Later on, also heterocyclic compounds including 2-vinyl-4H-1,3-dithiine (6) and 3-vinyl-3,4-dihydro1,2-dithiine (7) were discovered [5]. The formation of these volatile sulfur compounds starts from alliin (9) [6], a non-volatile precursor that is stored in garlic and related plants and only degraded into sulfur volatiles upon wounding by the pyridoxal phosphate (PLP) dependent alliinase (Scheme 1B) [7]. This initial enzyme-catalyzed reaction yields one equivalent of allyl- 
A)<smiles>C=CCSSCCC</smiles><smiles>C=CCSS(=O)CC=C</smiles>

5<smiles>C=CCSSCC=C</smiles><smiles>C=CC1SC=CCS1</smiles>

6<smiles>C=CCSSSCC=C</smiles>

3<smiles>C=CC1CC=CSS1</smiles>

7<smiles>C=CCSSSSCC=C</smiles><smiles>C=CC1C=CCSS1</smiles>

8

B)
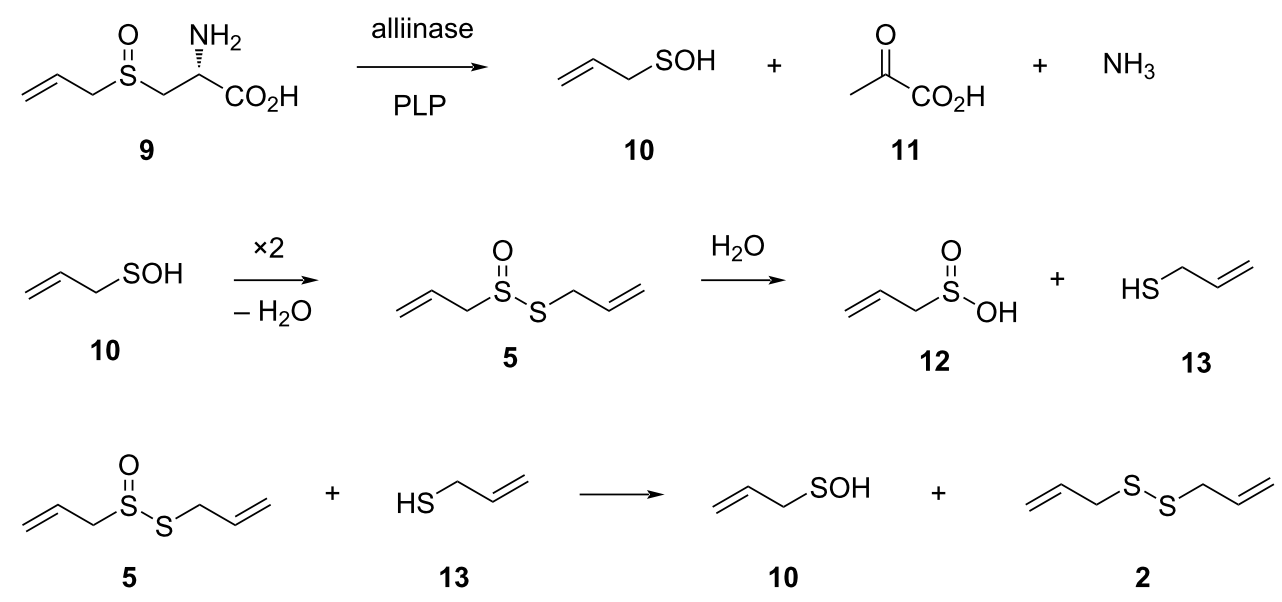

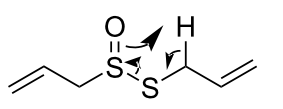

5<smiles>CCCC</smiles><smiles>C=CC[SeH]=O</smiles>

10

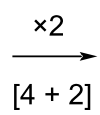

14

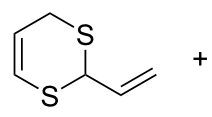

6<smiles>C=CC1CC=CSS1</smiles>

7

Scheme 1: Volatile allyl sulfides. A) Compounds known from garlic oil, B) mechanism of formation from alliin (9) by the PLP-dependent allinase (PLP: pyridoxalphosphate) and subsequent spontaneous reactions.

sulfenic acid (10), pyruvic acid (11), and ammonia from 9, followed by a series of proposed spontaneous reactions $[5,8]$. Through these transformations, acid $\mathbf{1 0}$ can undergo a dimerization with elimination of water to allicin (5). The hydrolysis of 5 results in allylsulfinic acid (12) and allyl thiol (13), the latter of which can react with another molecule of $\mathbf{5}$ to yield $\mathbf{1 0}$ and $\mathbf{2}$. Alternatively, 5 can decompose to $\mathbf{1 0}$ and thioacroleine (14) by a Cope elimination, which explains the formation of the heterocycles 6 and 7 by dimerization through a $[4+2]$ cycloaddition [5]. Compounds 6 and 7 were also reported to be formed from 5 during gas chromatographic (GC) analysis by an unknown mechanism [9] (7 was confused with its double bond regioisomer 3-vinyl-3,6-dihydro-1,2-dithiine (8) in this study [5]). Under these conditions the formation of the heterocyclic disulfides $\mathbf{7}$ and $\mathbf{8}$ may not involve a dimerization of $\mathbf{1 4}$, as a [4+2] cycloaddition is not a preferred gas-phase reaction.
The ecology of marine bacteria in their interaction with algae is particularly interesting in which the bacteria can promote the algal growth, but can also kill their host $[10,11]$. For both processes, the phytohormone indole-3-acetic acid is used as a messenger molecule [10]. For the macroalga Ulva mutabilis the presence of bacteria from the Roseobacter group is even mandatory for proper algal development, and 3-(dimethylsulfonio)propanoate (DMSP) is used as a chemotactic signal by the bacteria attracting them towards the algal host [12]. Many bacteria and fungi also release sulfur volatiles $[13,14]$ that are especially important headspace constituents from marine bacteria of the Roseobacter group [15-17]. In these organisms, sulfur volatiles are to a large extent generated from algal (DMSP), a metabolite that is produced in massive amounts by algae [18], thus giving another example for the complex interactions between marine bacteria and algae. Known DMSP degradation pathways include its hydrolysis to dimethyl sulfide 
(DMS) and 3-hydroxypropanoic acid (15) by the enzyme DddD [19], or the lysis to DMS and acrylic acid (16) for which various enzymes including DddL [20], DddP [21], DddQ [22], DddY [23], DddW [24], and DddK [25] have been described (Scheme 2A). Furthermore, a demethylation pathway is known through which DMSP is first converted into methylmercaptopropanoic acid (17) by the tetrahydrofolate $\left(\mathrm{FH}_{4}\right)$-dependent demethylase, DmdA (Scheme 2B) [26]. Compound 17 can be transformed into the coenzyme A thioester 18 by the CoA ligase DmdB, followed by FAD-dependent oxidation to the $\alpha, \beta$-unsaturated compound 19 by DmdC. The attack of water to the Michael acceptor catalyzed by the enoyl-CoA hydratase DmdD yields the hemithioacetal $\mathbf{2 0}$ that spontaneously collapses to methanethiol (MeSH) and malonyl-CoA semialdehyde (21). This compound further degrades to acetaldehyde (22) through the thioester hydrolysis and decarboxylation [27].

Feeding of (methyl- $\left.{ }^{2} \mathrm{H}_{6}\right)$ DMSP to Phaeobacter inhibens DSM 17395 and Ruegeria pomeroyi DSM 15171 resulted in the efficient uptake of labelling into dimethyl disulfide (DMDS), the oxidative dimerization product from $\mathrm{MeSH}$, showing the activity of the demethylation pathway in these bacteria. However, knockout of the $d m d A$ gene in $R$. pomeroyi still gave a low incorporation of labelling into DMDS, suggesting the presence of another gene responsible for the demethylation activity [28]. Also the labelling from $\left({ }^{34} \mathrm{~S}\right) \mathrm{DMSP}$ was efficiently incorporated into DMDS and dimethyl trisulfide (DMTS) [29]. Our previous investigations have also demonstrated that synthetic, i.e., non-natural DMSP analogues such as 3-(ethylmethyl)sulfoniopropanoate (EMSP), 3-(diethylsulfonio)propanoate (DESP), 3-(dimethylselenio)propanoate (DMSeP; this compound is also formed naturally in Spartina alterniflora in the presence of sodium selenate [30]), and even 3-(dimethyltellurio)propanoate (DMTeP) are converted by the demethylation pathway into ethanethiol, methaneselenol, and methanetellurol, respectively, that further react to various volatiles containing EtS, MeSe, and MeTe groups [31]. The in vitro incubations of these DMSP analogues with recombinant DddQ and DddW from $R$. pomeroyi and DddP from $P$. inhibens demonstrated that all substrate analogues can be degraded through the lysis pathway into the corresponding dialkyl chalcogenides; only DMTeP was not cleaved by DddQ [32]. Here we describe the synthesis of the new DMSP analogues 3-(allylmethylsulfonio)propanoate (AllMSP) and 3-(diallylsulfonio)propanoate (DAllSP) and their
A)<smiles>O=C(O)CCO</smiles>

15

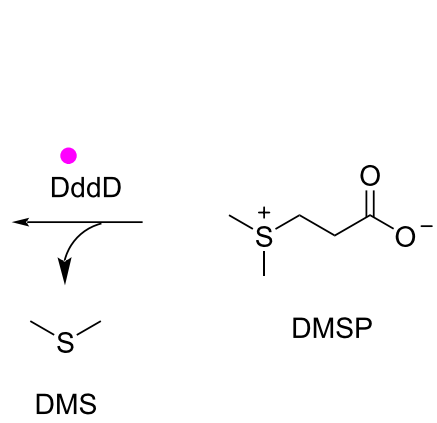

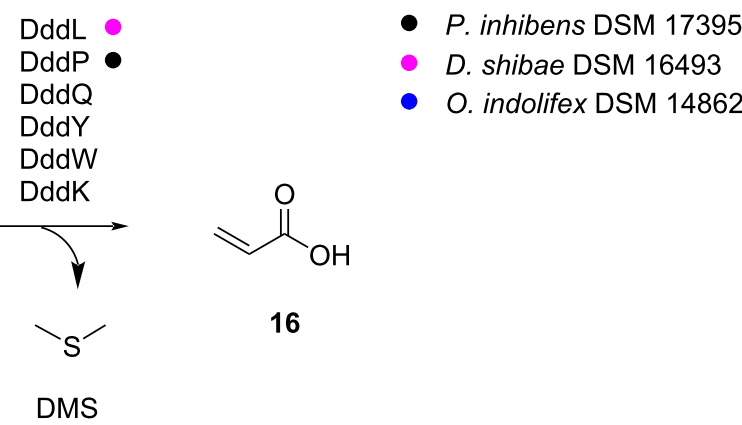

B)<smiles>C[S+](C)CCC(=O)O</smiles>

DMSP

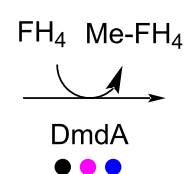<smiles>CS/C=C/C(=O)SOCO</smiles>

19

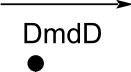

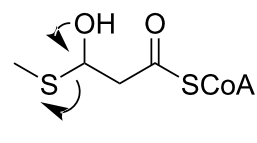

20

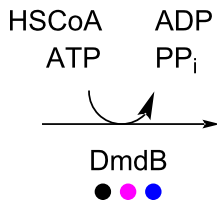

17<smiles>CSCCC(=O)OCCO</smiles>

18

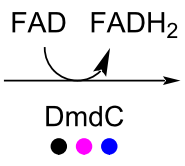

$\bullet \bullet \bullet$

Scheme 2: Degradation of DMSP by marine bacteria. A) Hydrolysis or lysis to DMS, B) demethylation pathway leading to MeSH. The color code shows which enzymes are encoded in the genomes of the strains investigated in this study. 
conversion into typical garlic odor constituents by marine bacteria from the Roseobacter group that do not naturally occur in these organisms.

\section{Results and Discussion}

3-(Diallylsulfonio)propanoate (DAllSP) and 3-(allylmethylsulfonio)propanoate (AllMSP) were synthesized by the acid-catalyzed addition of allyl methyl sulfide and diallyl sulfide, respectively, to acrylic acid (Scheme 3). The obtained DMSP analogues were fed to marine broth agar plate cultures of three strains from the Roseobacter group with fully sequenced genomes, including P. inhibens DSM 17395, Dinoroseobacter shibae DSM 16493, and Oceanibulbus indolifex DSM 14862. In all cases the bacterial cultures released a strong garlic-like odor, presumptively due to a degradation of the DMSP derivatives to sulfur-containing volatiles, similar to the compounds known from garlic, through one of the pathways shown in Scheme 2. The emitted volatiles were captured on charcoal filter traps using a closed-loop stripping apparatus (CLSA) [33], followed by the extraction of the filters with $\mathrm{CH}_{2} \mathrm{Cl}_{2}$ and analysis by gas chromatography-mass spectrometry (GC-MS) of the resulting extracts. Most of the compounds were readily identified by the comparison of their mass spectra and retention indices to published data. Every experiment was performed in triplicate to check for the reproducibility of the results. For comparison, the<smiles>C=CC(=O)O</smiles>

16

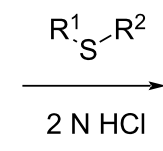<smiles>[R][SH+]([R])CCC(=O)O</smiles>

DAllSP $\left(R^{1}=R^{2}=\right.$ allyl, $\left.43 \%\right)$ AllMSP $\left(R^{1}=\right.$ allyl, $\left.R^{2}=M e, 54 \%\right)$

Scheme 3: Synthesis of DMSP derivatives volatiles from all three strains grown on marine broth medium without the addition of DMSP or its analogues have been reported before [31].

Feeding of DAllSP to $P$. inhibens resulted in the production of sulfur volatiles including several allyl derivatives (Figure 1, Figure 2A, Table 1, and Figure S1 in Supporting Information File 1). Besides the methylated sulfur compounds dimethyl trisulfide (31), dimethyl tetrasulfide (33), and $S$-methyl methanethiosulfonate (28) that were reported previously from P. inhibens [31], large amounts of diallyl sulfide (29) were observed, pointing to an efficient degradation of DAllSP through the lysis pathway, for which the DMSP lyase DddP can account in this organism (Scheme 2). Furthermore, the compounds allyl methyl disulfide (30), diallyl disulfide (2), allyl methyl trisulfide (32), and traces of diallyl trisulfide (3) and allyl methyl tetrasulfide (34) were observed. The formation of these compounds is explainable by the deallylation of DAllSP to 3-(allylsulfanyl)propanoic acid (37) and further degradation to allyl thiol (13) through the enzymes of the demethylation pathway that is fully established in $P$. inhibens by genes coding for DmdA-D (Scheme 4A). In the presence of air thiol 13 can then undergo an oxidative dimerization, or react analogously with MeSH to form allyl methyl disulfide (30, Scheme 4B). Similar oxidations requiring one additional unit of hydrogen sulfide can lead to the trisulfides $\mathbf{3}$ and $\mathbf{3 2}$ (Scheme 4C), while higher polysulfides such as $\mathbf{3 4}$ can arise through a metathesis reaction of two trisulfides (Scheme 4D). Also traces of methyl 3-(allylsulfanyl)propanoate (24), methyl 3-(methyldisulfanyl)propanoate (25), and methyl 3-(allyldisulfanyl)propanoate (26) were observed. While the presence of $\mathbf{2 4}$ can be explained by the $O$-methylation of the DmdA product 37 with $S$-adenosylmethionine (SAM, Scheme 4E), compounds 25 and 26 require a second deallylation of $\mathbf{3 7}$ to 3-mercaptopropanoic acid (38) possibly by DmdA, the reaction with a corresponding thiol $\mathrm{MeSH}$ or 13, and $O$-methylation (Scheme $4 \mathrm{~F}$ ).<smiles>[R]SCCC(=O)OC</smiles>

$23(\mathrm{R}=\mathrm{Me})$

$24(\mathrm{R}=$ allyl)

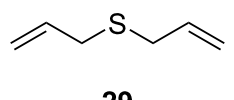

29<smiles>[R]SSCCC(=O)OC</smiles>

$25(\mathrm{R}=\mathrm{Me})$

$26(\mathrm{R}=$ allyl $)$<smiles>COC(=O)CCS(C)(=O)=O</smiles>

27<smiles>CSS(C)(=O)=O</smiles>

\footnotetext{
$\mathrm{R}^{1^{-S}}{ }^{-S^{-S}}{ }^{-R^{2}}$

$31\left(R^{1}=R^{2}=M e\right)$

$32\left(R^{1}=\right.$ Me, $R^{2}=$ allyl $)$

$3\left(R^{1}=R^{2}=\right.$ allyl $)$
}

$\mathrm{R}^{1^{-} \mathrm{S}} \mathrm{S}^{-\mathrm{S}} \mathrm{S}^{-\mathrm{R}^{2}}$

$33\left(R^{1}=R^{2}=M e\right)$

$34\left(R^{1}=\mathrm{Me}, \mathrm{R}^{2}=\right.$ allyl $)$

$35\left(R^{1}=R^{2}=\right.$ allyl $)$ 
A)

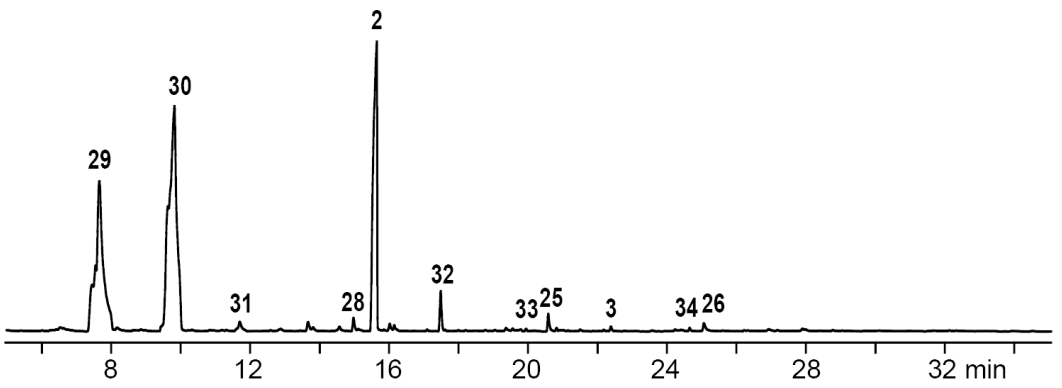

B)

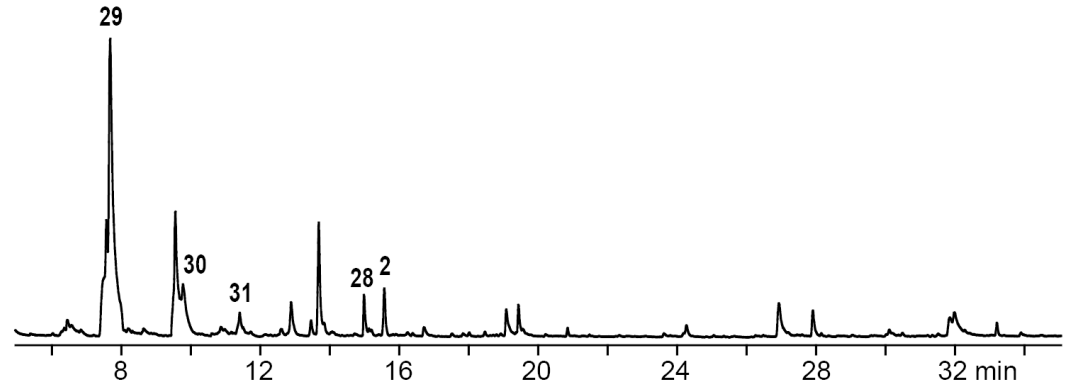

C)

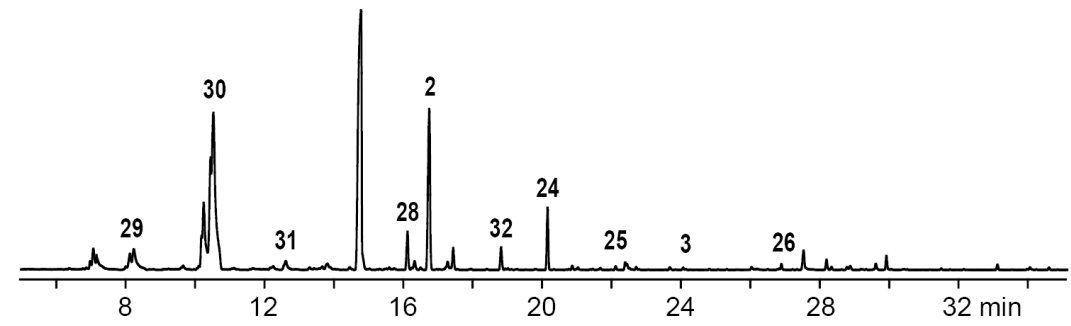

Figure 2: Total ion chromatograms of CLSA extracts obtained from feeding experiments with DAllSP fed to A) P. inhibens, B) D. shibae, and C) $O$. indolifex. Numbers at peaks refer to compounds in Figure 1. Peaks without numbers are unidentified.

Table 1: Volatiles from agar plate cultures fed with DAIISP.

\begin{tabular}{|c|c|c|c|c|c|}
\hline Compound ${ }^{\mathrm{a}}$ & I & $I_{\text {lit. }} \mathrm{b}$ & P. in. ${ }^{\mathrm{C}}$ & D. sh. ${ }^{\mathrm{c}}$ & O. in ${ }^{\mathrm{c}}$ \\
\hline diallyl sulfide $(29)^{*}$ & 849 & $848[34]$ & $\bullet \bullet$ & $\bullet \bullet \bullet$ & 00 \\
\hline allyl methyl disulfide (30) & 910 & $912[34]$ & $\bullet$ & $\bullet \bullet \bullet$ & 000 \\
\hline dimethyl trisulfide $(\mathbf{3 1})^{\star}$ & 967 & $970[35]$ & $\bullet$ & $\bullet \circ \bullet$ & 00 \\
\hline$S$-methyl methanethiosulfonate $(\mathbf{2 8})^{*}$ & 1063 & $1068[35]$ & $\bullet \bullet$ & $\bullet \bullet$ & 00 \\
\hline diallyl disulfide $(\mathbf{2})^{*}$ & 1074 & $1075[34]$ & $\bullet \bullet$ & $\bullet \bullet \bullet$ & 00 \\
\hline allyl methyl trisulfide (32) & 1136 & $1133[36]$ & $\bullet \bullet$ & ०० & 000 \\
\hline methyl 3-(allylsulfanyl)-propanoate (24) & 1177 & - & 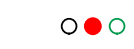 & ○०० & 00 \\
\hline dimethyl tetrasulfide (33) & 1216 & $1215[37]$ & $\bullet \bullet \bullet$ & 000 & 000 \\
\hline methyl 3-(methyldisulfanyl)-propanoate $(25)^{*}$ & 1236 & - & $\bullet$ & $0 \circ \bullet$ & $\bullet \circ$ \\
\hline diallyl trisulfide (3) & 1300 & $1300[38]$ & $\bullet \bullet$ & 000 & $\bullet \circ$ \\
\hline allyl methyl tetrasulfide (34) & 1382 & $1371[39]$ & $\bullet \bullet$ & ००० & 000 \\
\hline methyl 3-(allyldisulfanyl)-propanoate $(\mathbf{2 6})^{*}$ & 1397 & - & $\bullet \bullet$ & $0 \circ \bullet$ & $\bullet \circ$ \\
\hline diallyl tetrasulfide (35) & 1551 & $1540[38]$ & 000 & $0 \circ 0$ & 000 \\
\hline
\end{tabular}

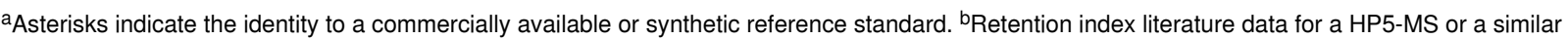
GC column. ${ }^{\mathrm{C}}$ Abbreviations are $P$. in. = Phaeobacter inhibens, $D$. sh. = Dinoroseobacter shibae, and $O$. in. = Oceanibulbus indolifex. Filled circles indicate the presence, non-filled circles indicate the absence of a compound in the headspace extract. The colors of the circles refer to the chromatograms in Figure 2 and Figure S1-S3 in Supporting Information File 1 with the same color. 
A)<smiles>[R]SCCC(=O)O</smiles>

B)

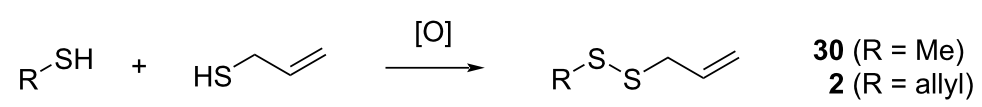

C)

$$
\mathrm{R}^{-\mathrm{SH}}+\mathrm{H}_{2} \mathrm{~S}+\mathrm{HS} \curvearrowright \stackrel{[\mathrm{O}]}{\longrightarrow} \quad \mathrm{R}^{-\mathrm{S} \mathrm{S}^{-}} \leadsto \begin{array}{r}
32(\mathrm{R}=\mathrm{Me}) \\
3(\mathrm{R}=\text { allyl) }
\end{array}
$$

D)

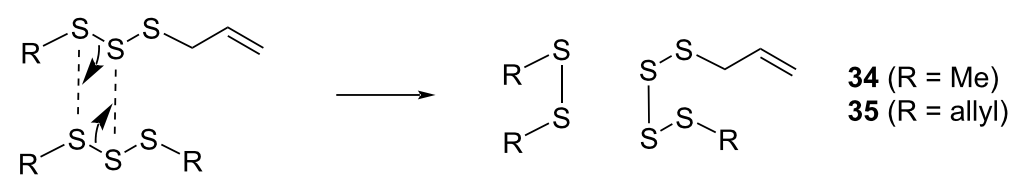

E)

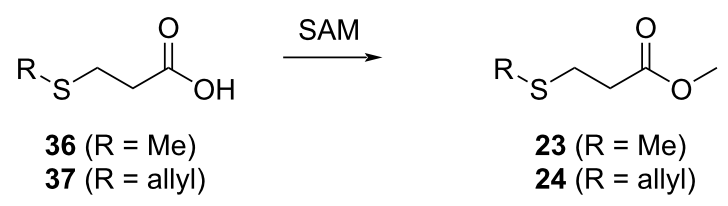

F)

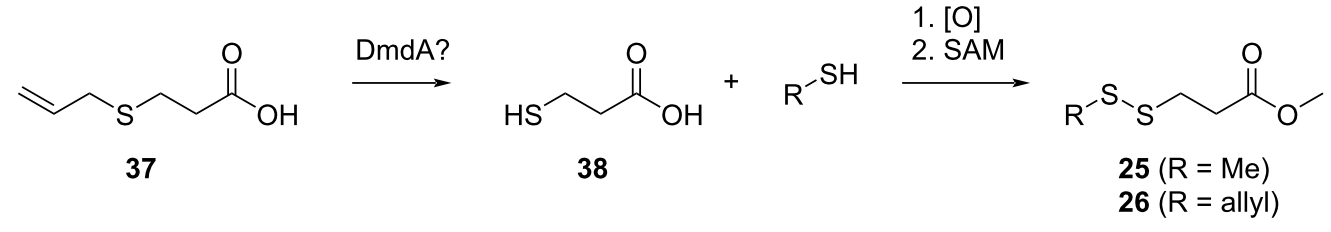

G)<smiles>C=CCSC[C@H](C=C)[Si](C)(C)CCC(=O)[O-]</smiles><smiles>C1CCCC1</smiles><smiles>C=CCSCC=C</smiles>

29<smiles>CSCCC(=O)O</smiles>

H)<smiles>COC(=O)CCSC</smiles>

23<smiles>ClC1CCCCC1</smiles><smiles>COC(=O)CCS(C)(=O)=O</smiles>

27

Scheme 4: Proposed mechanisms for the formation of sulfur volatiles from DAllSP and AlIMSP.

Very similar patterns of volatiles were obtained in the feeding experiments of DAllSP with D. shibae and $O$. indolifex (Figure 2B,C, Table 1 and Figures S2 and S3 in Supporting Information File 1). An additionally observed compound in one analysis of $O$. indolifex was diallyl tetrasulfide (35). Both organisms also encode the DMSP demethylation pathway in their genomes, but with missing $d m d D$ genes in both cases. A possible explanation is, that another enoyl-CoA hydratase, e.g., from fatty acid degradation, may functionally substitute for DmdD. Dinoroseobacter shibae additionally encodes genes for the DMSP hydrolase DddD and the DMSP lyase DddL, explaining the formation of $\mathbf{2 9}$, while no DMSP hydrolase or 
lyase is found in O. indolifex. Still, compound 29 is observed within this organism, but in lower quantities than in $P$. inhibens or $D$. shibae, and may point to the presence of another, yet unidentified type of DMSP lyase in this organism, because control experiments with medium plates with DAllSP added did not show a spontaneous degradation to $\mathbf{2 9}$ that could explain its observation.

The compound identification was based on a comparison to an authentic standard or of mass spectra to data base spectra in our MS libraries and confirmed for most cases by comparison of the retention indices to literature data, only for the mass spectrum of 26 no data base hit was returned. Therefore, a structural suggestion for this compound was based on the observed fragmentation pattern of the mass spectrum (Figure 3A). The molecular ion together with its isotope pattern pointed to two sulfur atoms, while the fragment ion at $m / z=64\left(\left[\mathrm{~S}_{2}\right]^{+}\right)$pointed to a disulfide. The fragment ions at $m / z=59\left(\left[\mathrm{C}_{2} \mathrm{O}_{2} \mathrm{H}_{3}\right]^{+}\right)$and $161\left([\mathrm{M}-\mathrm{OMe}]^{+}\right)$indicated a methyl ester, and the series of $m / z=105\left(\left[\mathrm{C}_{3} \mathrm{H}_{5} \mathrm{~S}_{2}\right]^{+}\right), 73\left(\left[\mathrm{C}_{3} \mathrm{H}_{5} \mathrm{~S}\right]^{+}\right)$, and $41\left(\left[\mathrm{C}_{3} \mathrm{H}_{5}\right]^{+}\right)$suggested an allyl disulfide. Taken together, the structure of methyl 3-(allyldisulfa-nyl)propanoate was delineated for compound $\mathbf{2 6}$ that was further supported by additional fragmentations as shown in Figure 3A. In addition, compound $\mathbf{2 6}$ was synthesized by a method reported previously for the related compound 25 [40], through dimerization of methyl 3-mercaptopropanoate (39) to dimethyl 3,3'-disulfanediyldipropanoate (40), followed by the $\mathrm{BF}_{3} \cdot \mathrm{OEt}_{2}$-mediated metathesis with 2 (Scheme $5 \mathrm{~A}$ ). The synthetic compound $\mathbf{2 6}$ was identical by mass spectrum and retention index to the unknown volatile.

The feeding of AllMSP to $P$. inhibens resulted in the formation of large amounts of methyl 3-(methylsulfanyl)propanoate (23) in addition to smaller quantities of methyl 3-(allylsulfanyl)propanoate (24, Figure 4A, Table 2 and Figure S4 in Supporting Information File 1). While compound $\mathbf{2 3}$ can arise from AllMSP by deallylation to 3-(methylsulfanyl)propanoic acid (36), potentially through DmdA, and $O$-methylation, the deriva-

A)
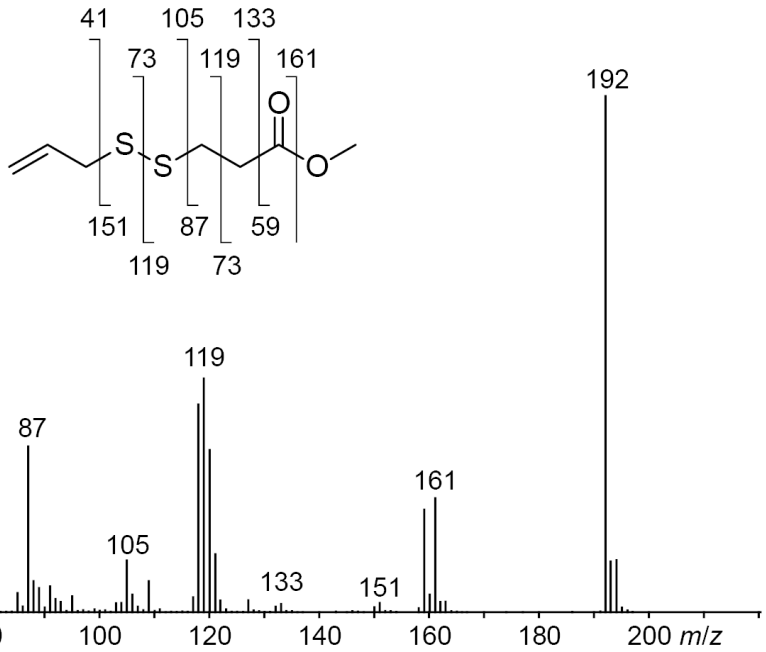

B)

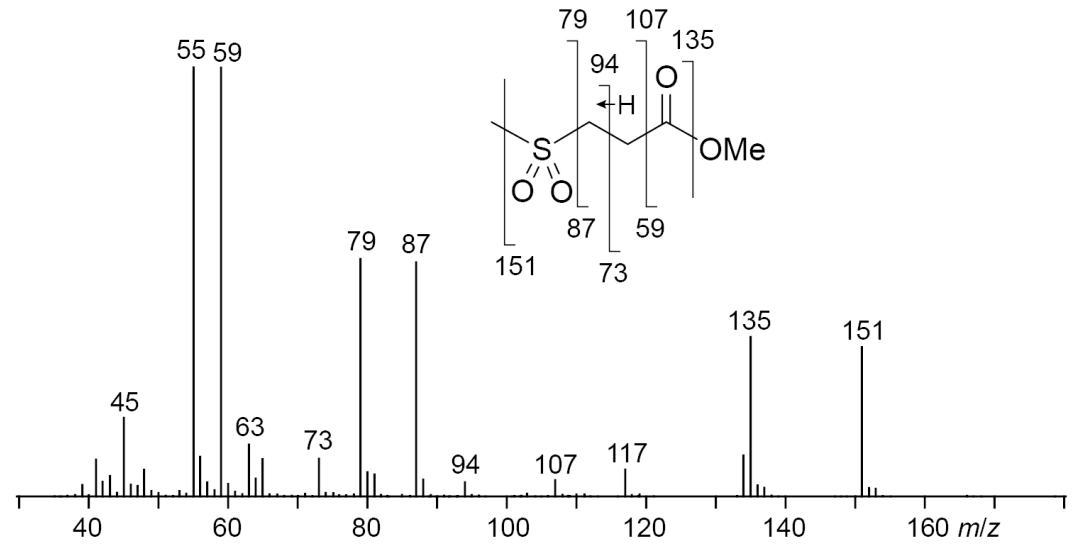

Figure 3: El mass spectrum and fragmentation pattern of the unknown volatiles A) methyl 3-(allyldisulfanyl)propanoate (26) and B) methyl 3-(methylsulfonyl)propanoate (27). 
A)
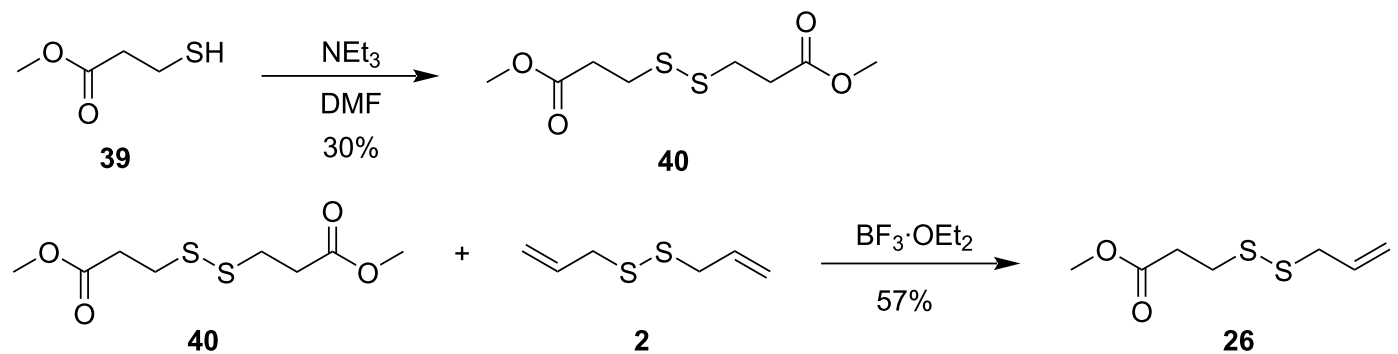

B)

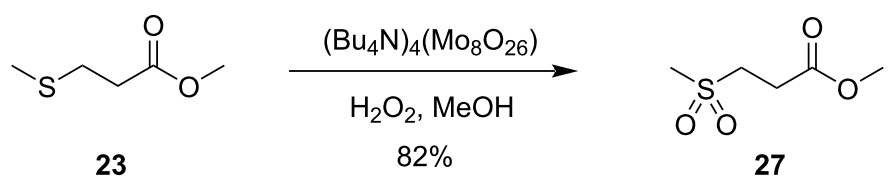

Scheme 5: Synthesis of A) methyl 3-(allyldisulfanyl)propanoate (26) and B) methyl 3-(methylsulfonyl)propanoate (27).

A)

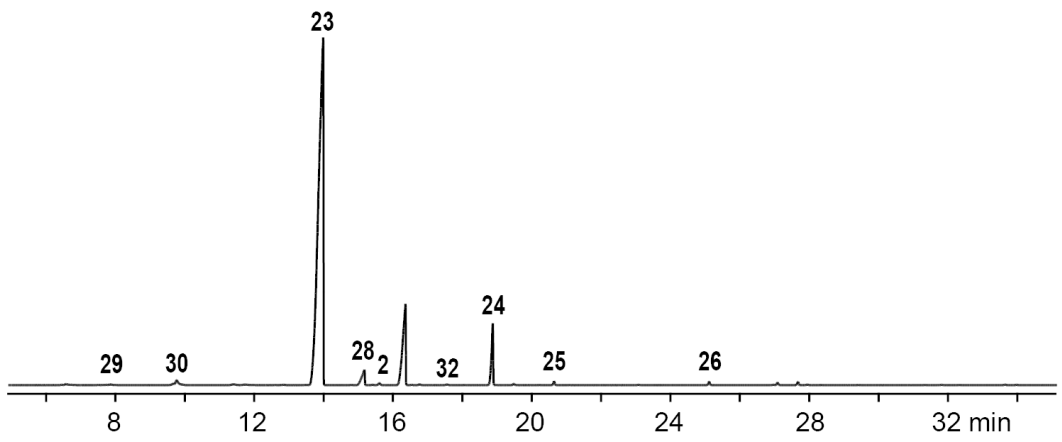

B)

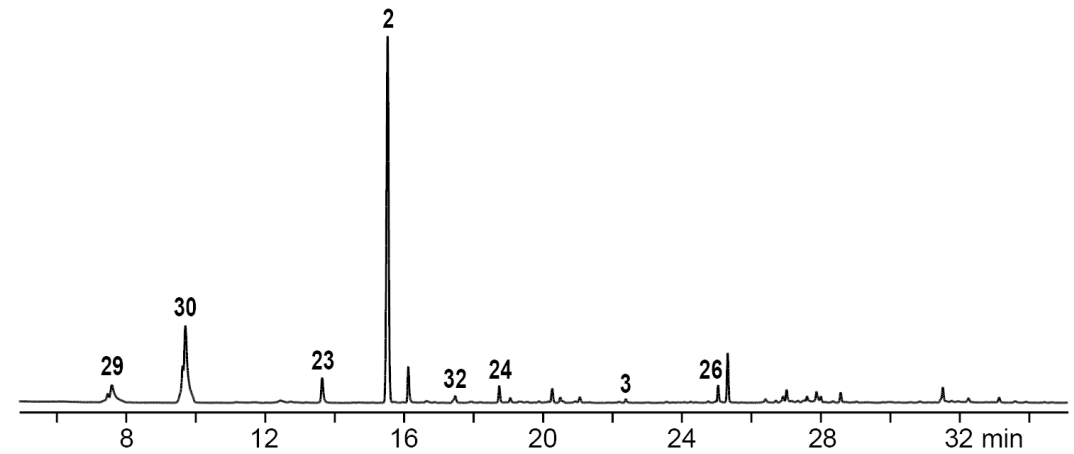

C)

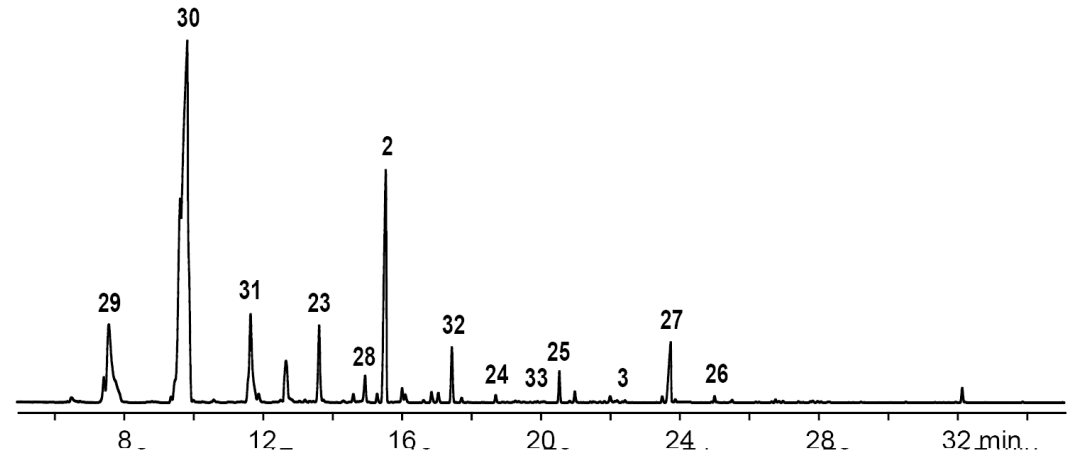

Figure 4: Total ion chromatograms of CLSA extracts obtained from the feeding experiments with AllMSP fed to A) $P$. inhibens, B) $D$. shibae, and C) O. indolifex. Numbers at peaks refer to compounds in Figure 1. Peaks without numbers are unidentified. 
Table 2: Volatiles from agar plate cultures fed with AllMSP.

\begin{tabular}{|c|c|c|c|c|c|c|}
\hline Compound $^{\mathrm{a}}$ & I & $l_{\text {lit. }}$ b & & P. in. ${ }^{\mathrm{C}}$ & D. sh. $^{\mathrm{c}}$ & O. in. ${ }^{\mathrm{c}}$ \\
\hline diallyl sulfide $(29)^{*}$ & 849 & $848[34]$ & 1 & $\bullet \circ \bullet$ & $\bullet \bullet$ & 000 \\
\hline allyl methyl disulfide (30) & 910 & $912[34]$ & 2 & $\bullet \bullet \bullet$ & $\bullet \bullet \bullet$ & $\bullet \bullet \bullet$ \\
\hline dimethyl trisulfide $(\mathbf{3 1})^{\star}$ & 967 & $970[35]$ & 3 & $\circ \circ \bullet$ & 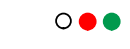 & 00 \\
\hline methyl 3-(methylsulfanyl)-propanoate $(23)^{*}$ & 1020 & $1023[41]$ & 4 & $\bullet \bullet \bullet$ & $\bullet \bullet$ & $\bullet$ \\
\hline S-methyl methanethiosulfonate $(\mathbf{2 8})^{*}$ & 1063 & $1068[35]$ & 5 & $\bullet \bullet \bullet$ & $\circ \bullet \bullet$ & $\bullet \bullet$ \\
\hline diallyl disulfide $(2)^{\star}$ & 1074 & $1075[34]$ & 6 & $\bullet \bullet \bullet$ & $\bullet \bullet$ & 00 \\
\hline allyl methyl trisulfide (32) & 1136 & $1133[36]$ & 7 & $\bullet \bullet \bullet$ & $\bullet \bullet$ & 00 \\
\hline methyl 3-(allylsulfanyl)propanoate (24) & 1177 & - & 8 & $\bullet \bullet \bullet$ & $\bullet \bullet$ & 00 \\
\hline dimethyl tetrasulfide (33) & 1216 & $1215[37]$ & 9 & ○०० & $\circ \bullet$ & $\bullet$ \\
\hline methyl 3-(methyldisulfanyl)-propanoate $(\mathbf{2 5})^{*}$ & 1236 & - & 10 & $\bullet \bullet \bullet$ & 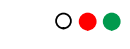 & 00 \\
\hline diallyl trisulfide (3) & 1300 & $1300[38]$ & 11 & ००० & $\bullet \bullet$ & 00 \\
\hline methyl 3-(methylsulfonyl)propanoate $(27)^{*}$ & 1353 & - & 12 & ००० & ○०० & 00 \\
\hline methyl 3-(allyldisulfanyl)propanoate $(26)^{*}$ & 1397 & - & 13 & $\bullet \bullet \bullet$ & $\bullet \bullet$ & $\bullet \circ$ \\
\hline
\end{tabular}

aAsterisks indicate the identity to a commercially available or synthetic reference standard. ${ }^{\mathrm{b}}$ Retention index literature data for a HP5-MS or a similar GC column. ${ }^{C}$ Abbreviations are $P$. in. = Phaeobacter inhibens, D. sh. = Dinoroseobacter shibae, and O. in. = Oceanibulbus indolifex. Filled circles indicate the presence, non-filled circles indicate the absence of a compound in the headspace extract. The colors of the circles refer to the chromatograms in Figure 4 and Figures S4-S6 in Supporting Information File 1 with the same color.

tive $\mathbf{2 4}$ may be formed analogously through intermediate $\mathbf{3 7}$ (Scheme $4 \mathrm{~A}$ and $\mathrm{E}$ ). The higher production of $\mathbf{2 3}$ in comparison to $\mathbf{2 4}$ suggests that the deallylation of AllMSP is more efficient than its demethylation, which is surprising, because naturally DmdA catalyzes a methyl-group transfer. This finding may reflect the high reactivity of the allyl group towards nucleophiles. Other compounds originating from AllMSP included the di- and trisulfides $\mathbf{2}, \mathbf{2 6}, \mathbf{3 0}$, and $\mathbf{3 2}$ that pointed to a breakdown of AllMSP to $\mathbf{1 3}$ through the DMSP demethylation pathway and subsequent oxidative polysulfide formation (Scheme 4A-C), but their formation was lower than from DAllSP, likely because of the discussed efficient deallylation of AllMSP. Small amounts of diallyl sulfide (29) were also detected, which is the formal lysis product of DAllSP, but not of AllMSP. In first instance, its formation from AllMSP was surprising, but it is explainable by a degradation of AllMSP to 13, followed by a nucleophilic attack at the allyl group of another AllMSP molecule (Scheme 4G). For D. shibae and $O$. indolifex the same pattern of compounds was found (Figure 4B,C, and Figures S5 and S6 in Supporting Information File 1), only the production of the deallylated compound $\mathbf{2 3}$ was lower, while in turn the production of the di- and trisulfides from 13 and of 29 was increased. This suggests that the deallylation of AllMSP by the DmdA variants in these organisms may be less efficient than was observed for $P$. inhibens. Besides these sulfur compounds, only $O$. indolifex, but not the other two strains, released another compound, 27, whose mass spectrum was not included in our databases. The analysis of the fragmentation pattern (Figure 3B) suggested that 27 could be methyl 3-(methylsulfonyl)propanoate, an oxidation product of 23. This hypothesis was confirmed by the chemical oxidation of $\mathbf{2 3}$, yielding methyl 3-(methylsulfonyl)propanoate with an identical mass spectrum and retention index to the volatile $\mathbf{2 7}$ (Scheme 5B). This compound may arise from 23 by the action of an oxygenase that is restricted to O. indolifex and not encoded in the genomes of the other two species. Its spontaneous formation from $\mathbf{2 3}$ in the presence of air can be excluded, because other cultures forming $\mathbf{2 3}$ did not show the release of 27.

\section{Conclusion}

Bacteria from the Roseobacter group can degrade DMSP analogues with $S$-allyl groups including AllMSP and DAllSP, likely with the participation of the enzymes for DMSP (hydro)lysis and from the DMSP demethylation pathway. Because MeSH can also originate from other sources, the DMSP derivatives used in this study can lead to products that can indicate which metabolic pathways are used for their conversion. Interestingly, the volatiles formed from AllMSP and DAllSP closely resemble flavoring compounds from garlic. The demethylation pathway with all four enzymes DmdABCD is fully established in $P$. inhibens, while genes for DmdD are missing in $D$. shibae and $O$. indolifex, suggesting that another enzyme with a low sequence homology may substitute for DmdD, leading to allylthiol and several sulfur volatiles derived from it in all three strains. The DMSP hydrolase DddD and the lyase DddL are present in D. shibae, and P. inhibens has a DMSP lyase DddP, which can explain the conversion of 
DAllSP into diallyl sulfide, while the reason for its formation in $O$. indolifex is currently unclear and may point to an unknown type of DMSP lyase in this organism. Since the observed patterns of allylated sulfur volatiles in the three investigated strains are different, it seems possible that the DMSP (hydro)lases and the enzymes from the DMSP demethylation pathway have different activities towards AllMSP and DAllSP. In vitro studies with recombinant purified enzymes and mutational work will be needed for more detailed insights to support our hypotheses regarding the involved enzymes in AllMSP and DAllSP breakdown and will be performed in our laboratories in the future.

\section{Experimental}

\section{Strains and culture condition}

Phaeobacter inhibens DSM 14862, Dinoroseobacter shibae DSM 16493, Oceanibulbus indolifex DSM 14862 were precultured in full strength marine broth medium (MB 2216, Roth) at $28{ }^{\circ} \mathrm{C}$ with shaking at $180 \mathrm{rpm}$ until the OD value reached about 1.0 .

\section{Feeding experiments and sampling of volatiles}

Headspace samplings for each strain were done in triplicates. For the feeding experiments, DAllSP or AlMSP $(1 \mathrm{mM})$ were added to the full strength marine broth agar medium (MB2216) after autoclavation. The medium was then transferred into glass Petri dishes. The agar plates were inoculated with the precultures $(400 \mu \mathrm{L})$, incubated for two days at $28^{\circ} \mathrm{C}$ and then subjected for headspace extraction to a CLSA [33] for $24 \mathrm{~h}$. The released volatiles were collected on charcoal filters (Chromtech, Idstein, Germany), followed by the extraction of the filters with dichloromethane $(50 \mu \mathrm{L})$, and analysis of the extracts by GC-MS. For comparison, blank experiments with MB medium alone and with MB agar plates spiked with DAllSP or AlMSP were performed in the same way. All the volatiles mentioned in Table 1 and Table 2 were not observed in the blank experiments.

\section{GC-MS}

The GC-MS analyses were carried out on a HP7890A GC system connected to a HP5975C mass selective detector fitted with a HP-5MS fused silica capillary column $(30 \mathrm{~m} \times 0.22 \mathrm{~mm}$ i.d., $0.25 \mu \mathrm{m}$ film, Hewlett-Packard). The conditions were: inlet pressure: $67 \mathrm{kPa}$, He $23.3 \mathrm{~mL} \mathrm{~min}^{-1}$; injection volume: $1 \mu \mathrm{L}$; injector: $250{ }^{\circ} \mathrm{C}$; transfer line: $300{ }^{\circ} \mathrm{C}$; electron energy: $70 \mathrm{eV}$. The GC was programmed as follows: $50{ }^{\circ} \mathrm{C}$ ( 5 min isothermic), increasing at $5{ }^{\circ} \mathrm{C} \mathrm{min}-1$ to $320{ }^{\circ} \mathrm{C}$ and operated in the splitless mode (60 s valve time); carrier gas $(\mathrm{He}): 1.2 \mathrm{~mL} \mathrm{~min}^{-1}$. The retention indices were determined from $n$-alkane standards $\left(\mathrm{C}_{8}-\mathrm{C}_{32}\right)$ [42].

\section{General synthetic methods}

All chemicals were purchased from TCI (Deutschland) or Sigma-Aldrich Chemie (Germany), and used without purification. Solvents were distilled and dried by standard methods. NMR spectra were recorded on a Bruker (Billerica, USA) Avance III HD Prodigy (500 MHz) or on an Avance III HD Cryo (700 MHz) NMR spectrometer. The spectra were referenced against solvent signals $\left({ }^{1} \mathrm{H} \mathrm{NMR}\right.$, residual proton signal: $\mathrm{D}_{2} \mathrm{O} \delta=4.79 \mathrm{ppm}, \mathrm{CDCl}_{3} \delta=7.26 \mathrm{ppm}, d_{6}$-DMSO $\delta=2.50 \mathrm{ppm} ;{ }^{13} \mathrm{C} \mathrm{NMR:} \mathrm{CDCl}_{3} \delta=77.16 \mathrm{ppm}, d_{6}$-DMSO $\delta=39.52 \mathrm{ppm})$. The coupling constants are given in Hz. IR spectra were recorded on a Bruker $\alpha$ spectrometer equipped with a diamond-ATR probe. The relative intensities of signals are indicated by w (weak), m (medium), and s (strong).

\section{Synthesis of allyl DMSP derivatives}

A mixture of acrylic acid $(0.72 \mathrm{~g}, 10 \mathrm{mmol})$ and diallyl sulfide or allylmethyl sulfide $(10 \mathrm{mmol})$ was treated with $2 \mathrm{~N} \mathrm{HCl}$ at $80^{\circ} \mathrm{C}$ for $4 \mathrm{~h}$. The reaction mixture was concentrated in vacuo and the residue was purified by silica gel column chromatography $\left(\mathrm{CH}_{2} \mathrm{Cl}_{2} / \mathrm{MeOH} 5: 1\right)$, followed by recrystallization from methanol/diethyl ether $1: 1$ to yield the pure compounds.

DAllSP·HCl. Yield: $960 \mathrm{mg}(4.32 \mathrm{mmol}, 43 \%) .{ }^{1} \mathrm{H}$ NMR $\left(\mathrm{D}_{2} \mathrm{O}, 700 \mathrm{MHz}\right) \delta 5.98(\mathrm{ddt}, J=17.5,10.2,7.4,2 \mathrm{H}), 5.73$ (d, $J=10.2,2 \mathrm{H}), 5.72(\mathrm{~d}, J=17.0,2 \mathrm{H}), 4.08(\mathrm{~d}, J=7.4,4 \mathrm{H}), 3.43$ $(\mathrm{t}, J=6.9,2 \mathrm{H}), 2.78(\mathrm{t}, J=6.9,2 \mathrm{H}) ;{ }^{13} \mathrm{C} \mathrm{NMR}\left(\mathrm{D}_{2} \mathrm{O}\right.$, $175 \mathrm{MHz}) \delta 177.05(\mathrm{C}), 127.65(2 \times \mathrm{CH}), 123.54\left(2 \times \mathrm{CH}_{2}\right)$, $41.53\left(2 \times \mathrm{CH}_{2}\right), 35.08\left(\mathrm{CH}_{2}\right), 31.68\left(\mathrm{CH}_{2}\right)$; HRMS-EI $(\mathrm{m} / \mathrm{z})$ : calcd for $\left[\mathrm{C}_{9} \mathrm{H}_{15} \mathrm{O}_{2} \mathrm{~S}\right]^{+}, 187.0787$; found, 187.0790.

AllMSP·HCl. Yield: $1.06 \mathrm{~g}(5.41 \mathrm{mmol}, 54 \%) .{ }^{1} \mathrm{H}$ NMR $\left(\mathrm{D}_{2} \mathrm{O}\right.$, $700 \mathrm{MHz}) \delta 5.96(\mathrm{ddt}, J=17.5,10.2,7.5,1 \mathrm{H}), 5.74(\mathrm{~d}, J=$ $10.2,1 \mathrm{H}), 5.71(\mathrm{~d}, J=17.2,1 \mathrm{H}), 4.13(\mathrm{dd}, J=13.4,7.4,1 \mathrm{H})$, 4.09 (dd, $J=13.4,7.5,1 \mathrm{H}), 3.58(\mathrm{dt}, J=13.7,6.9,1 \mathrm{H}), 3.47$ (dt, $J=13.5,6.7,1 \mathrm{H}), 3.04(\mathrm{t}, J=6.8,2 \mathrm{H}), 2.91(\mathrm{~s}, 3 \mathrm{H})$; ${ }^{13} \mathrm{C}$ NMR $\left(\mathrm{D}_{2} \mathrm{O}, 175 \mathrm{MHz}\right) \delta 173.77(\mathrm{C}), 128.19(\mathrm{CH}), 122.74$ $\left(\mathrm{CH}_{2}\right), 43.82\left(\mathrm{CH}_{2}\right), 35.84\left(\mathrm{CH}_{2}\right), 28.75\left(\mathrm{CH}_{2}\right), 21.72\left(\mathrm{CH}_{3}\right)$; HRMS-EI $(\mathrm{m} / \mathrm{z})$ : calcd for $\left[\mathrm{C}_{7} \mathrm{H}_{13} \mathrm{O}_{2} \mathrm{~S}\right]^{+}, 161.0631$; found, 161.0630 .

\section{Synthesis of dimethyl \\ 3,3'-disulfanediyldipropanoate (40)}

A solution of methyl 3-mercaptopropanoate $(6.00 \mathrm{~g}, 50.0 \mathrm{mmol}$, 1.0 equiv) and triethylamine $(5.05 \mathrm{~g}, 50.0 \mathrm{mmol})$ in DMF $(10 \mathrm{~mL})$ was treated for $24 \mathrm{~h}$ at $40{ }^{\circ} \mathrm{C}$. The reaction was quenched by the addition of water and the aqueous phase extracted with ethyl acetate. The extract was dried with $\mathrm{MgSO}_{4}$ and then concentrated in vacuo. The residue was purified by silica column chromatography (cyclohexane/EtOAc 5:1) to give compound 40 (1.80 g, $7.56 \mathrm{mmol}, 30 \%)$ as pale yellow oil. TLC 
$R_{\mathrm{f}} 0.44$ (cyclohexane/EtOAc 10:3); IR (diamond-ATR) ṽ: 2998 (w), 2952 (w), $2845(\mathrm{w}), 2256(\mathrm{w}), 1730(\mathrm{~m}), 1436(\mathrm{w}), 1354$ (w), $1240(\mathrm{w}), 1215(\mathrm{w}), 1195(\mathrm{w}), 1171(\mathrm{w}), 1139(\mathrm{w}), 1046$ (w), $1017(\mathrm{w}), 979(\mathrm{w}), 907(\mathrm{w}), 822(\mathrm{w}), 726(\mathrm{~m}), 648(\mathrm{w})$, $435(\mathrm{w}) \mathrm{cm}^{-1} ;{ }^{1} \mathrm{H} \mathrm{NMR}\left(\mathrm{CDCl}_{3}, 500 \mathrm{MHz}\right) \delta 3.64(\mathrm{~s}, 6 \mathrm{H}), 2.87$ $(\mathrm{t}, J=7.2,4 \mathrm{H}), 2.68(\mathrm{t}, J=7.2,4 \mathrm{H}) \mathrm{ppm} ;{ }^{13} \mathrm{C} \mathrm{NMR}\left(\mathrm{CDCl}_{3}\right.$, $125 \mathrm{MHz}) \delta 172.11(2 \times \mathrm{C}), 51.90\left(2 \times \mathrm{CH}_{3}\right), 33.93\left(2 \times \mathrm{CH}_{2}\right)$, $33.16\left(2 \times \mathrm{CH}_{2}\right) \mathrm{ppm}$.

\section{Synthesis of methyl \\ 3-(allyldisulfanyl)propanoate (26)}

To a solution of dimethyl 3,3'-disulfanediyldipropanoate (40, $0.50 \mathrm{~g}, 2.10 \mathrm{mmol}, 1.0$ equiv) and diallyl disulfide (2, $0.31 \mathrm{~g}$, $2.10 \mathrm{mmol}, 1.0$ equiv) in dry DCM $(10 \mathrm{~mL})$ and $\mathrm{CH}_{3} \mathrm{NO}_{2}$ $(10 \mathrm{~mL})$ at $0{ }^{\circ} \mathrm{C} \mathrm{BF}_{3} \cdot \mathrm{OEt}_{2}(30 \mathrm{mg}, 0.21 \mathrm{mmol}, 0.1$ equiv) was added. The reaction mixture was stirred at $0{ }^{\circ} \mathrm{C}$ for $3 \mathrm{~h}$ and at room temperature overnight. The reaction was quenched by the addition of water and extracted with ethyl acetate. The extracts were dried with $\mathrm{MgSO}_{4}$ and concentrated in vacuo. The obtained residue was purified by silica gel column chromatography (cyclohexane/EtOAc 5:1) to give compound $26(0.23 \mathrm{~g}$, $1.20 \mathrm{mmol}, 57 \%)$. TLC $R_{\mathrm{f}}=0.72$ (cyclohexane $/$ EtOAc $=1: 1$ ); IR (diamond-ATR) ̃̃: 3082 (w), 2950 (w), 2845 (w), 1736 (s), 1634 (w), 1435 (w), 1354 (w), 1277 (w), 1240 (w), $1216(w)$, $1172(w), 1144(w), 1017(w), 985(w), 922(w), 859(w), 820$ (w), $756(\mathrm{w}), 722(\mathrm{w}), 669(\mathrm{w}), 582(\mathrm{w}), 478(\mathrm{w}), 435(\mathrm{w})$ $\mathrm{cm}^{-1} ;{ }^{1} \mathrm{H} \mathrm{NMR}\left(\mathrm{CDCl}_{3}, 500 \mathrm{MHz}\right) \delta 5.83$ (ddt, $J=17.1,9.9$, $7.3,1 \mathrm{H}), 5.19$ (ddt, $J=16.9,1.3,1.3,1 \mathrm{H}), 5.14(\mathrm{dm}, J=10.0$, $1 \mathrm{H}), 3.69(\mathrm{~s}, 3 \mathrm{H}), 3.32(\mathrm{dm}, J=7.3,2 \mathrm{H}), 2.91(\mathrm{t}, J=7.2,2 \mathrm{H})$, $2.72(\mathrm{t}, J=7.2,2 \mathrm{H}) \mathrm{ppm} ;{ }^{13} \mathrm{C} \mathrm{NMR}\left(\mathrm{CDCl}_{3}, 125 \mathrm{MHz}\right) \delta$ $172.14(\mathrm{C}), 132.71(\mathrm{CH}), 119.40\left(\mathrm{CH}_{2}\right), 52.04\left(\mathrm{CH}_{3}\right), 41.60$ $\left(\mathrm{CH}_{2}\right), 33.87\left(\mathrm{CH}_{2}\right), 33.40\left(\mathrm{CH}_{2}\right)$ ppm; HRMS-EI $(\mathrm{m} / \mathrm{z})$ : calcd for $\left[\mathrm{C}_{7} \mathrm{H}_{12} \mathrm{O}_{2} \mathrm{~S}_{2}\right]^{+}, 192.0273$; found, 192.0289 .

\section{Synthesis of methyl}

\section{3-(methylsulfonyl)propanoate (27)}

To a stirred solution of $\left[\left(n-\mathrm{C}_{4} \mathrm{H}_{9}\right)_{4} \mathrm{~N}\right]_{4}\left(\mathrm{Mo}_{8} \mathrm{O}_{26}\right)(5 \mathrm{mg}$, $2.5 \mu \mathrm{mol}, 0.001$ equiv) [43] in methanol (4 mL), methyl 3-methylthiopropanoate (335 mg, $2.50 \mathrm{mmol}, 1.0$ equiv) was added at $40{ }^{\circ} \mathrm{C}$. After the reaction mixture was stirred for 5 minutes, $30 \%$ hydrogen peroxide solution $(0.52 \mathrm{~mL}, 0.57 \mathrm{~g}$, $5.0 \mathrm{mmol}, 2.0$ equiv) was added dropwise. The color of the reaction mixture changed from colorless to yellow. The reaction mixture was stirred for 30 minutes at room temperature. After completion of the reaction, EtOAc $(10 \mathrm{~mL})$ was added, causing precipitation of the catalyst. The catalyst was filtered off, the filtrate was dried with $\mathrm{MgSO}_{4}$ and concentrated in vacuo to give pure $27(0.34 \mathrm{~g}, 2.05 \mathrm{mmol}, 82 \%)$ as colorless solid. TLC $R_{\mathrm{f}} 0.17$ (cyclohexane/EtOAc 1:1); IR (diamondATR) ̃ : $3014(\mathrm{w}), 2948(\mathrm{w}), 2932(\mathrm{w}), 1762(\mathrm{~m}), 1687(\mathrm{w})$ 1442 (w), 1433 (w), 1418 (w), 1375 (w), 1331 (w), 1306 (m), $1373(\mathrm{~m}), 1259$ (m), 1203 (w), $1180(\mathrm{w}), 1131(\mathrm{~m}), 1056(\mathrm{w})$, $1004(\mathrm{w}), 988(\mathrm{w}), 971(\mathrm{w}), 956(\mathrm{w}), 898(\mathrm{w}), 786(\mathrm{w}), 774(\mathrm{w})$, $749(\mathrm{w}), 601(\mathrm{w}), 514(\mathrm{w}), 505(\mathrm{w}), 441(\mathrm{w}) \mathrm{cm}^{-1} ;{ }^{1} \mathrm{H}$ NMR $\left(d_{6}\right.$-DMSO, $\left.500 \mathrm{MHz}\right) \delta 3.63(\mathrm{~s}, 3 \mathrm{H}), 3.37(\mathrm{t}, J=7.5,2 \mathrm{H}), 3.01$ $(\mathrm{s}, 3 \mathrm{H}), 2.78(\mathrm{t}, J=7.5,2 \mathrm{H}) \mathrm{ppm} ;{ }^{13} \mathrm{C} \mathrm{NMR}\left(d_{6}\right.$-DMSO, $125 \mathrm{MHz}) \delta 170.79(\mathrm{C}), 51.88\left(\mathrm{CH}_{3}\right), 49.14\left(\mathrm{CH}_{2}\right), 40.21$ $\left(\mathrm{CH}_{3}\right), 26.89\left(\mathrm{CH}_{2}\right) \mathrm{ppm}$.

\section{Supporting Information}

\section{Supporting Information File 1}

Additional total ion chromatograms and copies of NMR spectra.

[https://www.beilstein-journals.org/bjoc/content/ supplementary/1860-5397-17-51-S1.pdf]

\section{Funding}

This work was funded by the DFG (SFB TR 51 "Roseobacter").

\section{ORCID ${ }^{\circledR}$ iDs}

Jeroen S. Dickschat - https://orcid.org/0000-0002-0102-0631

\section{References}

1. Wertheim, T. Ann. Chem. Pharm. 1844, 51, 289-315. doi:10.1002/jlac.18440510302

2. Semmler, F. W. Arch. Pharm. (Weinheim, Ger.) 1892, 230, 434-443. doi:10.1002/ardp.18922300603

3. Cavallito, C. J.; Buck, J. S.; Suter, C. M. J. Am. Chem. Soc. 1944, 66, 1952-1954. doi:10.1021/ja01239a049

4. Shang, A.; Cao, S.-Y.; Xu, X.-Y.; Gan, R.-Y.; Tang, G.-Y.; Corke, H.; Mavumengwana, V.; Li, H.-B. Foods 2019, 8, 246. doi:10.3390/foods8070246

5. Block, E.; Ahmad, S.; Jain, M. K.; Crecely, R. W.; Apitz-Castro, R.; Cruz, M. R. J. Am. Chem. Soc. 1984, 106, 8295-8296. doi:10.1021/ja00338a049

6. Stoll, A.; Seebeck, E. Helv. Chim. Acta 1948, 31, 189-210. doi:10.1002/hlca.19480310140

7. Stoll, A.; Seebeck, E. Helv. Chim. Acta 1949, 32, 197-205. doi:10.1002/hlca.19490320129

8. Block, E. Angew. Chem., Int. Ed. Engl. 1992, 31, 1135-1178. doi:10.1002/anie.199211351

9. Brodnitz, M. H.; Pascale, J. V.; Van Derslice, L. J. Agric. Food Chem. 1971, 19, 273-275. doi:10.1021/jf60174a007

10. Segev, E.; Wyche, T. P.; Kim, K. H.; Petersen, J.; Ellebrandt, C.; Vlamakis, H.; Barteneva, N.; Paulson, J. N.; Chai, L.; Clardy, J.; Kolter, R. eLife 2016, 5, e17473. doi:10.7554/elife.17473

11. Barak-Gavish, N.; Frada, M. J.; Ku, C.; Lee, P. A.; DiTullio, G. R.; Malitsky, S.; Aharoni, A.; Green, S. J.; Rotkopf, R.; Kartvelishvily, E.; Sheyn, U.; Schatz, D.; Vardi, A. Sci. Adv. 2018, 4, eaau5716. doi:10.1126/sciadv.aau5716

12. Kessler, R. W.; Weiss, A.; Kuegler, S.; Hermes, C.; Wichard, T. Mol. Ecol. 2018, 27, 1808-1819. doi:10.1111/mec.14472 
13. Schulz, S.; Dickschat, J. S. Nat. Prod. Rep. 2007, 24, 814-842. doi:10.1039/b507392h

14. Dickschat, J. S. Nat. Prod. Rep. 2017, 34, 310-328. doi:10.1039/c7np00003k

15. Dickschat, J. S.; Wagner-Döbler, I.; Schulz, S. J. Chem. Ecol. 2005, 31 , 925-947. doi:10.1007/s10886-005-3553-9

16. Dickschat, J. S.; Reichenbach, H.; Wagner-Döbler, I.; Schulz, S. Eur. J. Org. Chem. 2005, 4141-4153. doi:10.1002/ejoc.200500280

17. Thiel, V.; Brinkhoff, T.; Dickschat, J. S.; Wickel, S.; Grunenberg, J.; Wagner-Döbler, I.; Simon, M.; Schulz, S. Org. Biomol. Chem. 2010, 8, 234-246. doi:10.1039/b909133e

18. Dickschat, J. S.; Rabe, P.; Citron, C. A. Org. Biomol. Chem. 2015, 13, 1954-1968. doi:10.1039/c4ob02407a

19. Todd, J. D.; Rogers, R.; Li, Y. G.; Wexler, M.; Bond, P. L.; Sun, L.; Curson, A. R. J.; Malin, G.; Steinke, M.; Johnston, A. W. B. Science 2007, 315, 666-669. doi:10.1126/science.1135370

20. Curson, A. R. J.; Rogers, R.; Todd, J. D.; Brearley, C. A.; Johnston, A. W. B. Environ. Microbiol. 2008, 10, 757-767. doi:10.1111/j.1462-2920.2007.01499.x

21. Todd, J. D.; Curson, A. R. J.; Dupont, C. L.; Nicholson, P.; Johnston, A. W. B. Environ. Microbiol. 2009, 11, 1376-1385. doi:10.1111/j.1462-2920.2009.01864.x

22. Todd, J. D.; Curson, A. R. J.; Kirkwood, M.; Sullivan, M. J.; Green, R. T.; Johnston, A. W. B. Environ. Microbiol. 2011, 13, 427-438. doi:10.1111/j.1462-2920.2010.02348.x

23. Curson, A. R. J.; Sullivan, M. J.; Todd, J. D.; Johnston, A. W. B. ISME J. 2011, 5, 1191-1200. doi:10.1038/ismej.2010.203

24. Todd, J. D.; Kirkwood, M.; Newton-Payne, S.; Johnston, A. W. B. ISME J. 2012, 6, 223-226. doi:10.1038/ismej.2011.79

25. Sun, J.; Todd, J. D.; Thrash, J. C.; Qian, Y.; Qian, M. C.; Temperton, B.; Guo, J.; Fowler, E. K.; Aldrich, J. T.; Nicora, C. D.; Lipton, M. S.; Smith, R. D.; de Leenheer, P.; Payne, S. H.; Johnston, A. W. B.; Davie-Martin, C. L.; Halsey, K. H.; Giovannoni, S. J. Nat. Microbiol. 2016, 1, 16065. doi:10.1038/nmicrobiol.2016.65

26. Howard, E. C.; Henriksen, J. R.; Buchan, A.; Reisch, C. R.; Bürgmann, H.; Welsh, R.; Ye, W.; González, J. M.; Mace, K.; Joye, S. B.; Kiene, R. P.; Whitman, W. B.; Moran, M. A. Science 2006, 314, 649-652. doi:10.1126/science.1130657

27. Reisch, C. R.; Stoudemayer, M. J.; Varaljay, V. A.; Amster, I. J.; Moran, M. A.; Whitman, W. B. Nature 2011, 473, 208-211. doi:10.1038/nature10078

28. Brock, N. L.; Citron, C. A.; Zell, C.; Berger, M.; Wagner-Döbler, I.; Petersen, J.; Brinkhoff, T.; Simon, M.; Dickschat, J. S. Beilstein J. Org. Chem. 2013, 9, 942-950. doi:10.3762/bjoc.9.108

29. Brock, N. L.; Menke, M.; Klapschinski, T. A.; Dickschat, J. S. Org. Biomol. Chem. 2014, 12, 4318-4323. doi:10.1039/c4ob00719k

30. Ansede, J. H.; Pellechia, P. J.; Yoch, D. C. Environ. Sci. Technol. 1999, 33, 2064-2069. doi:10.1021/es9812296

31. Dickschat, J. S.; Zell, C.; Brock, N. L. ChemBioChem 2010, 11, 417-425. doi:10.1002/cbic.200900668

32. Burkhardt, I.; Lauterbach, L.; Brock, N. L.; Dickschat, J. S. Org. Biomol. Chem. 2017, 15, 4432-4439. doi:10.1039/c7ob00913e

33. Grob, K.; Zürcher, F. J. Chromatogr. 1976, 117, 285-294. doi:10.1016/0021-9673(76)80005-2

34. Ansorena, D.; Astiasarán, I.; Bello, J. J. Agric. Food Chem. 2000, 48, 2395-2400. doi:10.1021/jf990931y

35. Kubec, R.; Drhová, V.; Velíšek, J. J. Agric. Food Chem. 1998, 46, 4334-4340. doi:10.1021/jf980379x
36. Ansorena, D.; Gimeno, O.; Astiasarán, I.; Bello, J. Food Res. Int. 2001, 34, 67-75. doi:10.1016/s0963-9969(00)00133-2

37. Bonaïti, C.; Irlinger, F.; Spinnler, H. E.; Engel, E. J. Dairy Sci. 2005, 88, 1671-1684. doi:10.3168/jds.s0022-0302(05)72839-3

38. Zoghbi, M. d. G. B.; Andrade, E. H. A.; Maia, J. G. S. Flavour Fragrance J. 2002, 17, 133-135. doi:10.1002/ffj.1051

39. Mnayer, D.; Fabiano-Tixier, A.-S.; Petitcolas, E.; Hamieh, T.; Nehme, N.; Ferrant, C.; Fernandez, X.; Chemat, F. Molecules 2014, 19, 20034-20053. doi:10.3390/molecules191220034

40. Hahnke, S.; Brock, N. L.; Zell, C.; Simon, M.; Dickschat, J. S.; Brinkhoff, T. Syst. Appl. Microbiol. 2013, 36, 39-48. doi:10.1016/j.syapm.2012.09.004

41. Beaulieu, J. C.; Grimm, C. C. J. Agric. Food Chem. 2001, 49, 1345-1352. doi:10.1021/jf0005768

42. van Den Dool, H.; Dec. Kratz, P. J. Chromatogr. 1963, 11, 463-471. doi:10.1016/s0021-9673(01)80947-x

43. Yang, C.; Jin, Q.; Zhang, H.; Liao, J.; Zhu, J.; Yu, B.; Deng, J. Green Chem. 2009, 11, 1401-1405. doi:10.1039/b912521n

\section{License and Terms}

This is an Open Access article under the terms of the Creative Commons Attribution License (https://creativecommons.org/licenses/by/4.0). Please note that the reuse, redistribution and reproduction in particular requires that the author(s) and source are credited and that individual graphics may be subject to special legal provisions.

The license is subject to the Beilstein Journal of Organic Chemistry terms and conditions: (https://www.beilstein-journals.org/bjoc/terms)

The definitive version of this article is the electronic one which can be found at: https://doi.org/10.3762/bjoc.17.51 